\title{
Relationship between Legibility and Speed of Handwriting with Underlying Perceptual-Motor Functions in Persian Language Students
}

\author{
Narges Rashidi ${ }^{1}$, Hamid Salehi ${ }^{2}$, Shila Safavi Homami ${ }^{3}$ \\ 1. Narges Rashidi, (M.A) University of Isfahan, Isfahan, Iran \\ 2. Hamid Salehi, (Ph.D) University of Isfahan, Isfahan, Iran \\ 3. Shila Safavi Homami, (Ph.D) University of Isfahan, Isfahan, Iran
}

\section{ARTICLE INFO}

Received May 2015

Accepted November 2015

\section{KEYWORDS:}

Dysfunction

Handwriting Legibility

Handwriting Speed

Perceptual-Motor Skills

\section{CITE:}

Rashidi, Salehi, Safavi Homami, Relationship between Legibility and Speed of Handwriting with Underlying Perceptual-Motor Functions in Persian Language Students, Research in sport management \& motor behavior, 2020: 9(18):36-51

\section{ABSTRACT}

The purpose of this inquiry was to examine the interrelations among handwriting legibility and speed, and underlying perceptual-motor skills in Persian language students. Seventy students ( 26 male, 44 female; $10.21 \pm 1.02$ yr; 30 poor and 40 good control hand writers) were assessed during a copying task. The children completed the visual-motor control (VMC), upper-limb speed and dexterity (ULSD), and upper-limb coordination (ULC) subtests of the Bruininks-Oseretsky test of motor proficiency (BOT). The poor group scored significantly lower on handwriting legibility and speed in comparison with classroom controls in the copying task. Correlation coefficients between perceptual-motor function scores with handwriting legibility, and with handwriting speed varied from -0.11 to 0.40 , and 0.17 to 0.39 respectively. Results showed that both legibility and speed predicted differences between students classified as "poor" and "good" hand writers. Results also showed that in the poor hand writers group, age, gender, BOT-ULC, and BOT-VMC were found to be significant predictors of legibility of handwriting, whereas gender and BOT-ULC were shown to be significant predictors of handwriting speed. The findings suggest that distinct perceptualmotor components may underlie writing during copying. Poor quality of handwriting of children seems to be particularly related to some sort of deficiency and dysfunction in perceptual-motor skills. Future studies should determine the possible benefit of interventions including stimulant in perceptual-motor functioning and handwriting performance, to enhance performance in these areas. 

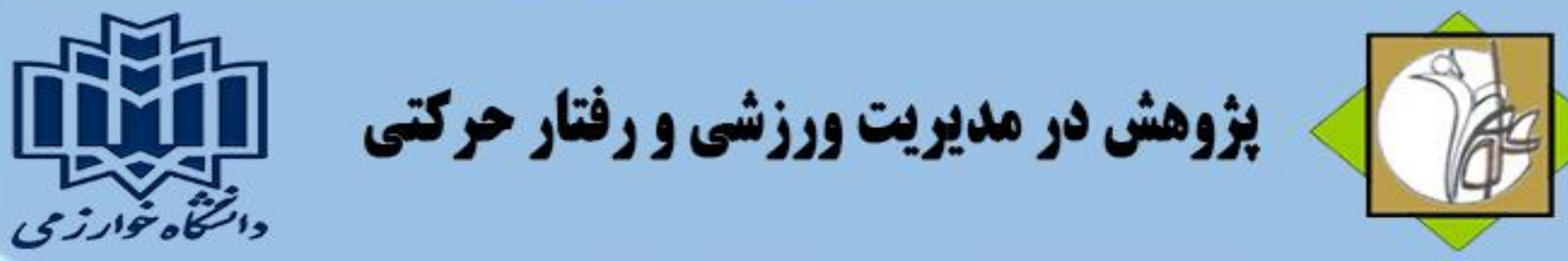

\section{ارتباط بين خوانايى و سـر عت نوشتن و عملكر د هاى ادراكى - حر كتى در دانش آمسوزان فارسىزبان \\ نر گس رشيدى'، حميد صالحى*'، شيلا صفوى همامى \\ ا. كارشناسى ارشد رفتار حركتى، دانشگاه اصفهان، اصفهان، ايران

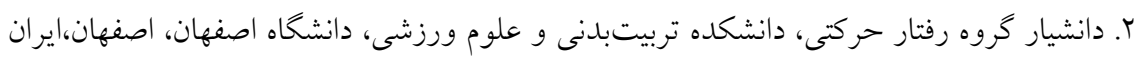

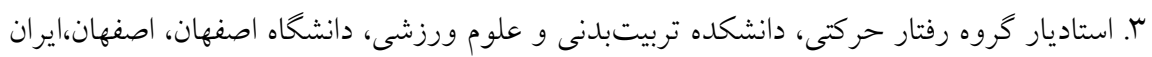

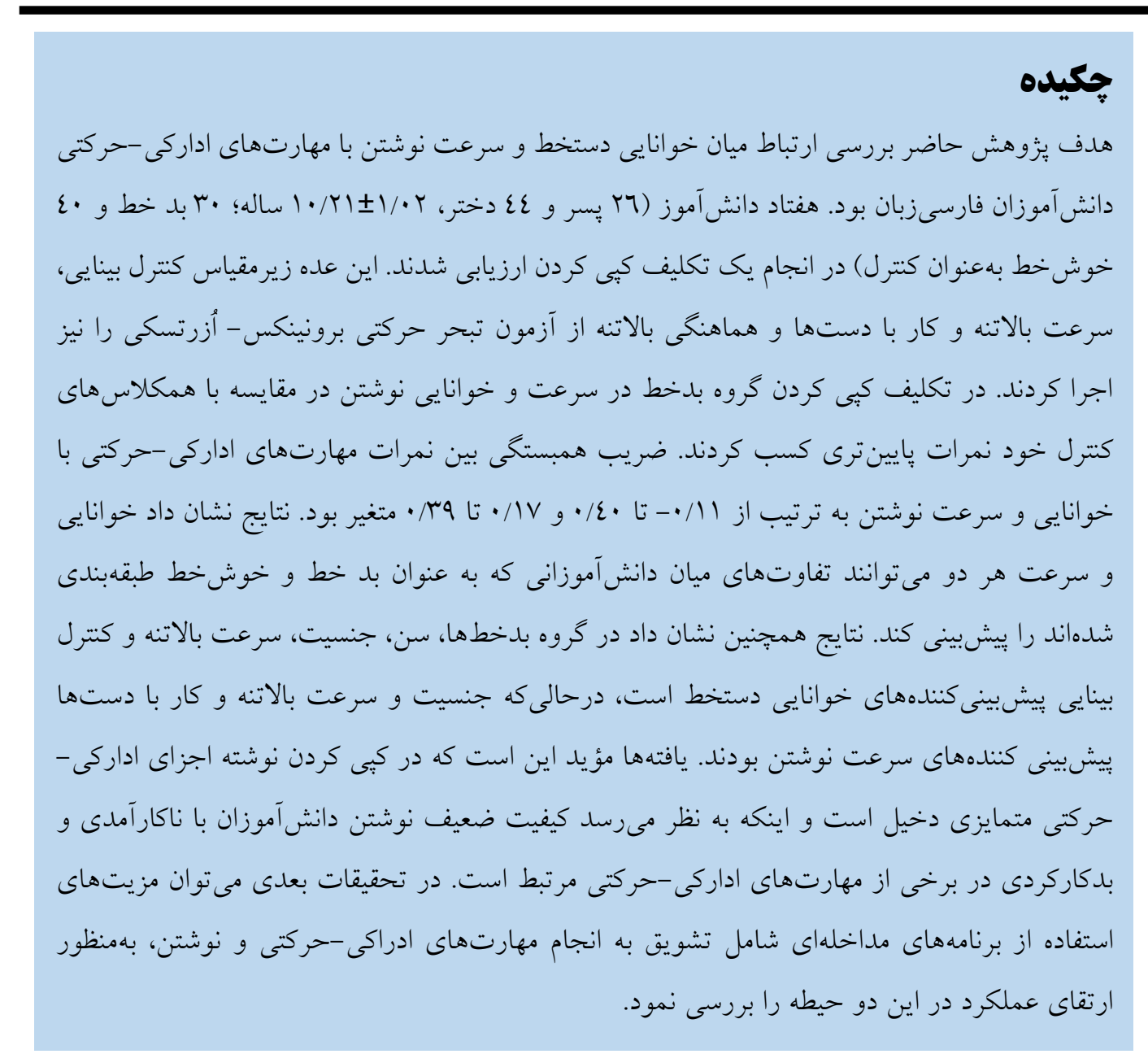

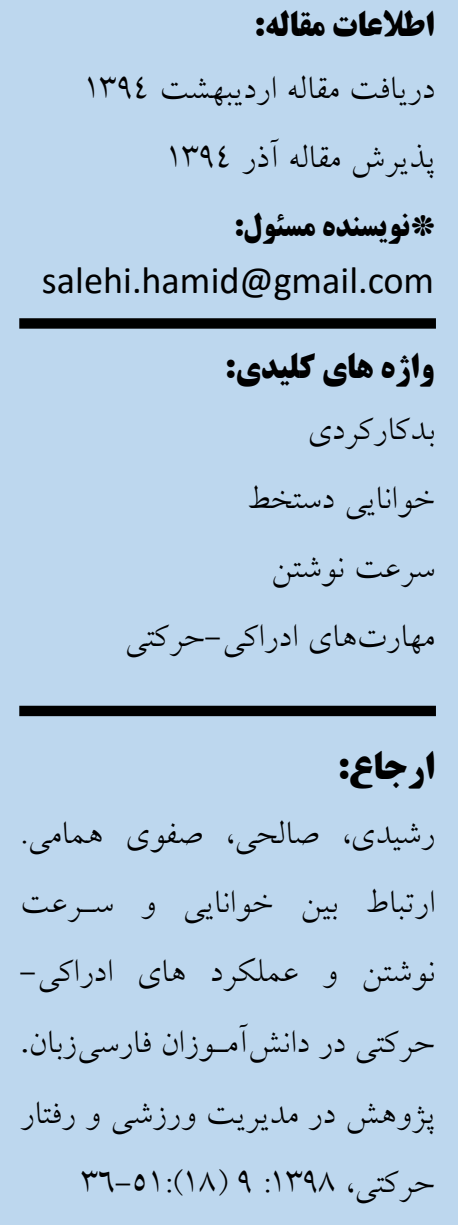

https://jrsm.khu.ac.ir/ 


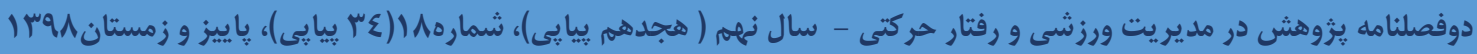

مقلدمه

نوشتن يك مهارت ادراكى -حركتى است كه در برقرارى ارتباط نقشى بسيار مهم دارد. تبحر در نوشتن يكى از ييشنيازهاى موفقيت تحصيلى است و مشكلاتى كه برخى از دانش آموزان با نوشتن دارند، مىتواند بيشرفت آنها به سطوح بالاتر را به تأخير بيندازد ( (, Y). متأسفانه مشكلات نوشتن ادر كودكان دبستانى، بهويزه در يسران معمول است. در تخمينهاى بينالمللى شيوع مشكلات نوشتارى بسته به بايههاى تحصيلى، معيارهاى انتخاب، و ابزارهاى مورداستفاده بين 0 تا Vادرصد برآورد شده است (r, §). تحقيقات داخلى نيز نشان داده از هر ...1 دانشآموز دبستانى فارسىزبان حدود با نفر ناتوانى خاص نوشتن دارند (0). تحقيقات نشان داده مشكلات نوشتارى (بدخطى) آثار زرفى روى خود ينداره، بيشرفت تحصيلى، طرز برخورد، و رفتارهاى دانشآموزان مى گذارد (T, V). در همين راستا، از طرف سازمان بهداشت جهانى امشكلات نوشتارى بهعنوان مانعى در مسير مشاركت در فعاليتهاى مدرسه، كه عنصر مفيدى در رشد طبيعى كودى است معرفىشده است (^).

براى مشخص كردن آثار منفى احتمالى بدخطى، لازم است متغيرهايى كه در ارزيابى فرايند اندازهيرى نقصهاى نوشتارى و سازو كارهاى زيربنايى مربوط به آنها مورداستفاده قرار مى گيرد مشخص شود. عليرغم اين نياز در بيشينه تحقيق در مورد متغيرهايى از نوشتن كه بايد مورد ارزيابى قرار كيرد توافق وجود ندارد. برخى مانند سويك، آرنتزن، و كارلسدوتير (9) معتقدند براى ارزيابى عملكرد نوشتن دانشآموزان بايد سرعت نوشتن در نظر گرفته شود. ديكران معتقدند بايد با استفاده از يك رويكرد تحليلى خوانايى آمشتن در قالب اجزايى مانند شكل حروف و ويزگى هاى فضايى در نظر گرفته شود ( • (). برخى از يزوهشكران نيز اعتقاددارند براى بررسى تبحر در نوشتن بايد هم سرعت و هم خوانايى توصيف شود و اين دو عامل مهمترين اجزاء عملكرد نوشتن هستند (V, II). اما باكمال تعجب تحقيقات معدودى را مىتوان يافت كه در آنها هم سرعت و هم خوانايى استفادهده باشد و در اين بزوهشهاى اندى نيز نتايج متفاوت و متناقضى كزارش شده

است (1).

علاوه بر بررسى اجزاى نوشتن (سرعت و دستخط)، لازم است سازو كارهاى زيربنايى دخيل در بدخطى نيز مشخص شود. محققين و نظريهيردازان معتقدند كه صحيحترين و مؤثرترين روش براى ارزيابى وضعيت نوشتن و طراحى برنامهاى

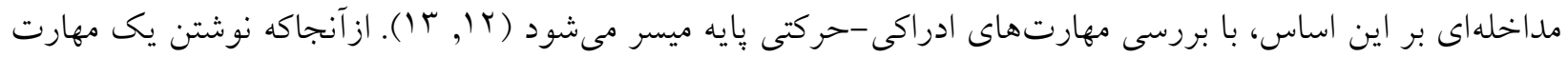
ادراكى -حركتى است مانند ساير مهارتهاى ادراكى -حركتى، عوامل زيربنايى متعددى در رشد و تكامل آن دخيلاند.

$1 \quad$ Handwriting difficulties

2 World Health Organization: WHO

3 Legibility

https://jrsm.khu.ac.ir/ 


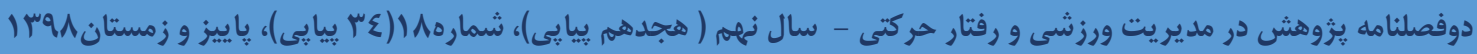

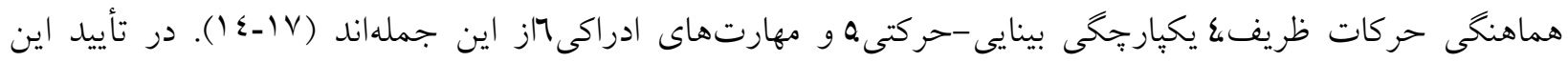

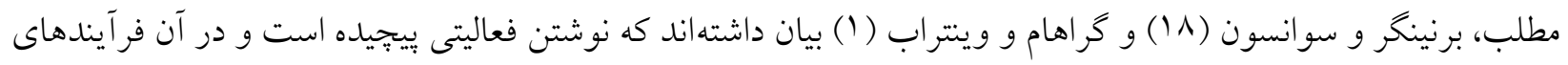
سطح پايين ادراكى -حركتى و فرآيندهاى سطح بالاى شناختى بهطور مداوم بر يكديكر تأثير مى كذارند. لازلو و بيرستو (Y) نيز بر اساس نظريههاى كنترل حركتى اظهار داشتهاند يُ خور اندهاى ادراكى -حركتى [مانند حس حركت] عامل اصلى براى رشد دستخط هستند.

همانطور كه بيان شد دو جزء اصلى متون نوشتارى خوانايى دستخط و سرعت نوشتن است. دستخط دانشآموزان را مىتوان بهطور مستقيم ديد و ارزيابى كرد. خوانايى دستخط ميزان قابليت تشخيص يك حرف در متن، و سرعت توانايى سريع نوشتن حروف در مدتى مشخص تعريفشده است (V) (Y). تسنگ و جو (I9) با مقايسه تفاوتهاى ادراكى -حركتى كودكان V تا II ساله كندنويس و طبيعى نشان دادهاند كه در كودكان طبيعى سرعت و ظرافت حركات اندام فوقانى، و در كودكان كند نويس حافظه و يكهارجّى بصرى-حركتى بيشبينى كنندهاى سرعت دستخط هستند. در يُزوهش فدر و

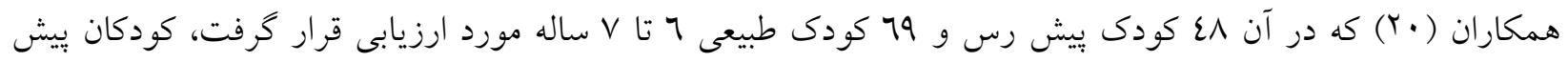
رس نمرات كمترى در سرعت و خوانايى به دست آوردند و عامل هاى مرتبط با خوانايى دستخط در اين تحقيق عبارت بودند از ادراى بصرى و هماهنكى دست-جشم، درحالى كه قدرت تشخيص انخشتان و توانايى دستكارى اشياء با سرعتيايين نوشتن مرتبط بود. وُمّن و همكاران (10) نيز نشان دادند، در كودكان داراى مشكلات نوشتارى، كيفيت ضعيف نوشتن (ناخوانايى) با بدكاركردى يكيارجكى بينايى -حركتى مرتبط است، درحالى كه در كودكان طبيعى، تنها بيشخويى كننده كيفيت دستخط هماهنخى حركتى ظريف است. كيزر، آلبرت، و دوين (7 (1) نيز نشان دادند يكيارجّى بينايى -حركتى و هماهنكى جشم-دست مىتوانند بهعنوان يِيشبينى كنندهاى كيفيت دستخط دانش آموزان مطرح باشند. درحالى كه كلين و همكاران (VIV) رابطه بين عملكرد دانش آموزان داراى مشكلات يادكيرى بايههاى سوم تا ششم در آزمونهاى اداركى -حركتى با خوانايى و سرعت نوشتن را بِايين برآورد كردهاند و نشان دادند كه ميزان كمى از واريانس

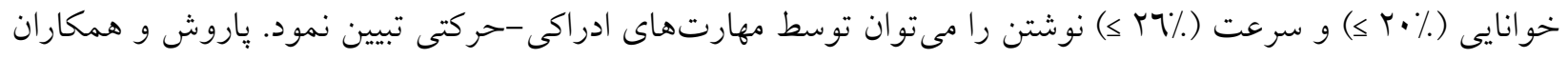
( ( ا) با بررسى ارتباط بين خوانايى دستخط، سرعت نوشتن و مهارتهاى ادراكى -حركتى دانشآموزان بايه سوم داراى مشكلات نوشتارى و معمولى در طى رونويسى و املا (ديكته) نشان دادهاند در رونويسى تنها خوانايى و در املا هر دو شاخص سرعت و خوانايى يِيشبينى كننده عملكرد نوشتن هستند.

\footnotetext{
4 Fine motor coordination
}

5 Visual-motor integration

6 


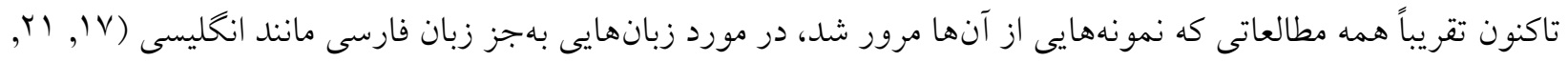

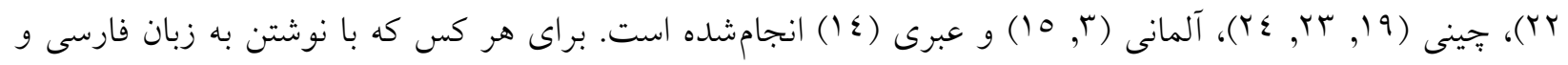
يكى ديخر از زبانهاى بين المللى مانند انخليسى يا هينى آشنا باشد مشهود است كه نوشتن به زبان فارسى ويزّى هاى فضايى -زمانى و هندسى متفاوت از زبانهاى فوق دارد. بهعنوانمثال نوشتن در فارسى معمولاً از راست به جِّب انجام مىشود و رسمالخط صحيح اغلب حروف از بالا به بايين و از راست به جِّ است. درصورتى كه بهعنوانمثال اغلب

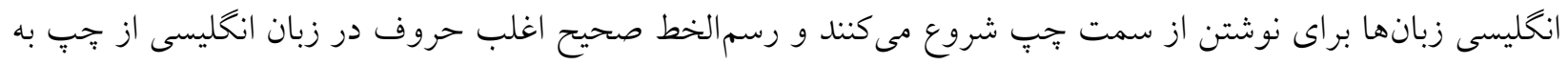
راست است. يا در زبان جينى راستاى نوشتن از بالا به يايين است. شكل هندسى حروف نيز در زبانهاى ذكر شده تفاوت هاى نسبتاً فاحشى با هم دارند. به لحاظ همين تفاوتها، به نظر مىرسد بهسختى مىتوان يافتهاى يزوهشهاى مشابه كه در زبانهايى غير از فارسى انجام شده را به دانشآموزان فارسىزبان تعميم داد. به همين دليل است كه تحقيقاتى

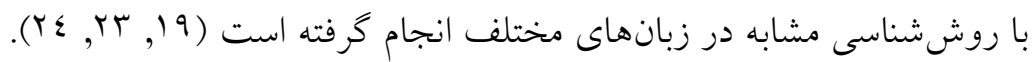

يزوهش هايى كه با موضوع بررسى نقش فرايندهاى ادراكى -حركتى زيربنايى نوشتن و دستخط در كشور انجامشدهاند، انخُشتشمارند و اغلب آنها روى نمونههايى از دانشآموزان انجام شده كه علاوه بر مشكلات نوشتارى از ديكر اختلالهاى يادكيرى مثل كمبود توجه/بيش فعالى (Y0) و كمتوان ذهنى (TY, TV, نيز رنج مى بردهاند. تحقيقات مختلف بدكاركردى مهارت هاى ادراكى -حركتى اين كودكان را مستند كردهاند (YN). بهطور مثال هداوندخانى و همكاران (YV) به بررسى رابطه بين حس حركت و اجزاى دستخط (جدانويسى، نوشتن حروف در مسير غيرمتعارف، درشت يا ريز نويسى و ...) برداختهاند و به اين نتيجه رسيدند كه بين اين متغيرها رابطه معنادار وجود ندارد. اين دسته از دانشآموزان از بدكاركردى توجه و يا سازو كارهاى شناختى (ضريب هوش) رنج مىبرند و بهتبع تفاوتهاى فاحشى با همتايان سالم خود دارند. همانطور كه مرور شد ناتوانى هاى نوشتن در بيشرفت تحصيلى و ياد گيرى دانش آموزان اهميت و نقش بسزايى دارند و مى تواند روى عملكرد تحصيلى آنان اثر گذار باشد. دانشآموزان داراى مشكلات دستخط ممكن است بهدرستى قادر به انجام اعمال حركتى موردنياز نوشتن يا رونويسى حروف و اشكال نباشند، همينطور ممكن است نتوانند دروندادهاى ادراكى را به اعمال حركتى ظريف (برونداد) تبديل كنند. اين دانش آموزان ممكن است در ساير كاركردهاى اداركى -حركتى مثل تشخيص روابط فضايى و واكنشهاى حركتى ضعف داشته باشند. بنابراين براى اينكه بتوان برنامهاى تمرينى مؤثر براى برطرف كردن ناتوانى هاى مرتبط با نوشتن طراحى و اجرا كرد، لازم است فر آيندهاى ادراكى -حركتى زيربنايى نوشتن و دستخط مشخص شود. طبق جستجوى انجامشده تا يشيشازاين مطالعهاى در زمينه تعيين سازوكارهاى ادراكى - حركتى 


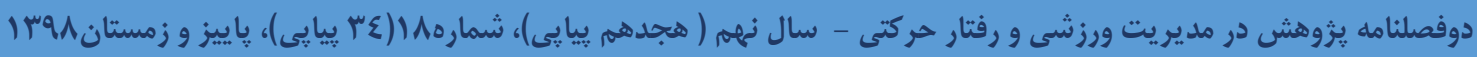

دخيل در سرعت نوشتن و خوانايى دستخط كه ممكن است در ضعف نوشتن كودكان فارسىزبان نقش داشته باشد انجام نشده است. بنابراين با در نظر گرفتن اهميت موضوع و بر اساس آنجه بيان شد، در يزوهش حاضر با ارزيابى سرعت نوشتن و خوانايى دستخط دانشآموزان فارسىزبان، ارتباط اين دو شاخص با فرآيندهاى رشد ادراكى - حركتى مورد بررسى قرار كرفت.

\section{روش شناسى بذووش}

\section{شركت كنندكان}

جامعه آمارى اين يزوهش دانش آموزان بايههاى سوم تا ينجم ابتدايى شهرستان ملاير است كه تعداد آنها در سال تحصيلى

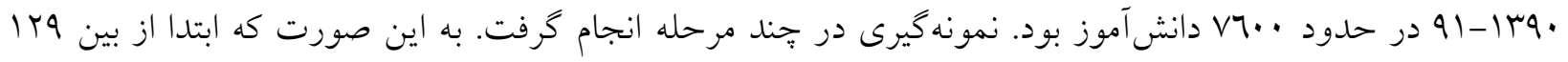
واحد آموزشى دولتى و غيردولتى بلصورت تصادفى عا مدرسه انتخاب شد. سبس در مدارس منتخب از ميان دانش آموزان يايه هاى سوم تا ينجم از هر كلاس دو دانشآموز انتخاب شد. معيار انتخاب اين بود كه معلم كلاس با شناختى كه از دانش آموزان داشته و براساس مشاهدات خود از نحوه نوشتن آنان، يك فرد را بهعنوان خوش خهطترين و يك فرد ديخر را بهعنوان بدخط ترين دانشآموز معرفى مىكرد. با اين وصف تعداد عمدانش آموز انتخاب شد. در بازه زمانى اجراى بثروهش عا دانش آموز به دلايل مختلف از جمله عدم توانايى اجراى آزمونهاى مهارتى يا انصراف از شركت داوطلبانه از جريان تحقيق كنار كذاشته شدند. بر اين اساس درنهايت يزوهش با •V دانش آموز (Tr يسر و عع دختر) با متوسط سن

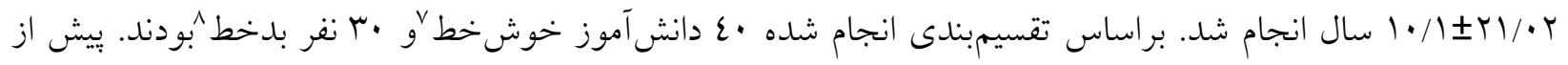
شروع يزوهش از ولى دانشآموزان شركت كننده در تحقيق رضايتنامه كتبى اخذ شد.

\section{ابزارها و طرز اجرا}

با توجه به تعريف خوانايى دستخط و مشابه يثزوهشهاى قبل [بهعنوان مثال: باروش و همكاران (Fl)، كيزر و همكاران

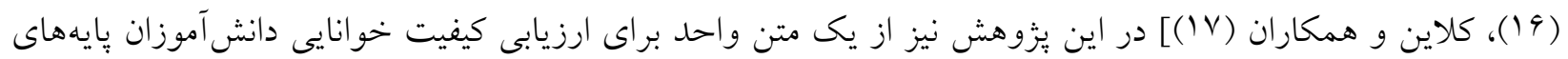
مختلف استفاده شد. به اين صورت كه ابتدا جلسهاى با ينج آموز گار باتجربه بركزار شد و توضيحات كاملى در مورد

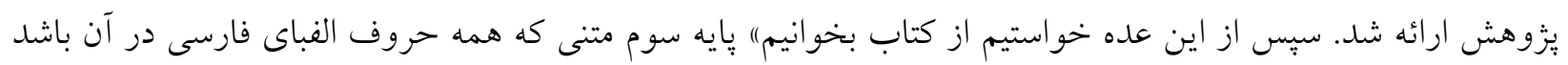
را انتخاب نمايند. متن انتخابشده توسط ده معلم (ارزياب) پايههاى سوم تا پنجم، در مورد تناسب تعداد كلمات دشوار

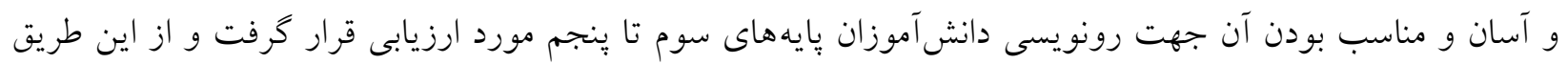

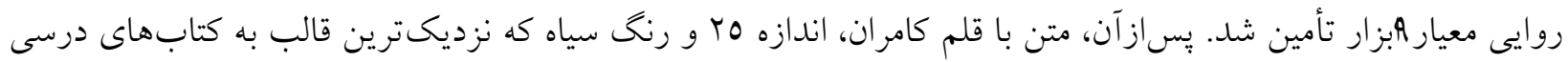

${ }^{7}$ Good handwriters

${ }^{8}$ Poor handwriters

${ }^{9}$ Criterion validity

https://jrsm.khu.ac.ir/ 


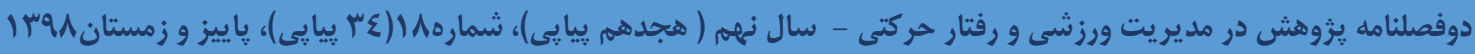

دانشآموزان است تحرير و روى يك بر گه كاغذ A4 جابٍ شد. بهمنظور بررسى خوانايى دستخط، جكليستى با ¥هار

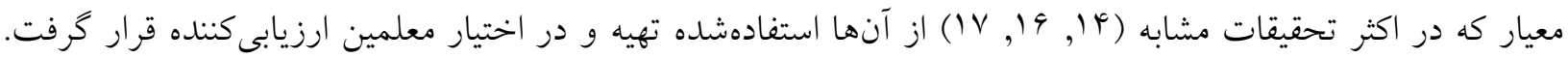
اين مقياسها عبارت بودند از: الف(شكل حروف، ب) فاصله بين حروف و كلمات، ج(تنظيم مسير و د) اندازه حروف. براى هر يك از معيارهاى فوق دو نمره در نظر كرفته شد. به اين معنى كه بالاترين امتياز در هر قسمت دو و پِيينترين صفر بود. مجموع امتيازهاى اين جهار معيار بهعنوان شاخص خوانايى متن در نظر گرفته شد. با اين اوصاف، خوش خط ترين متن امتياز هشت و بدخطترين متن امتياز صفر را كسب مىكرد. يس از جمعآورى نمونه متن رونويسى شده شركت كنندكان، متنها بهطور جداكانه در اختيار ارزيابها قرار گرفت تا مورد ارزيابى قرار كيرد. بايايى اين روش در يزٔوهش مقدماتى بررسى شد. به اين صورت كه از ده ارزياب موردنظر درخواست شد متنهاى نوشتهشده توسط يك

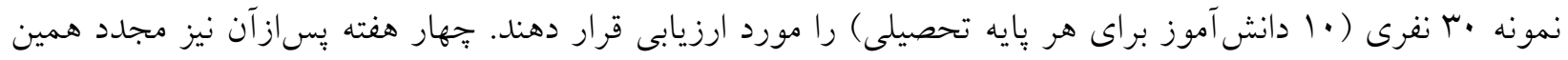
كار تكرار شد. ضريب يايايى بين ارزيابها با استفاده از ضريب همبستكى درون ردهاى •• ICC = 0.92, F 12.02, p > 001 و ضريب يايايى باز آزمايى با استفاده از ضريب همبستكى گشتاورى بيرسون r = 0.97 محاسبه شد كه هر دو ضريب بسيار بالا و موردقبول هستند.

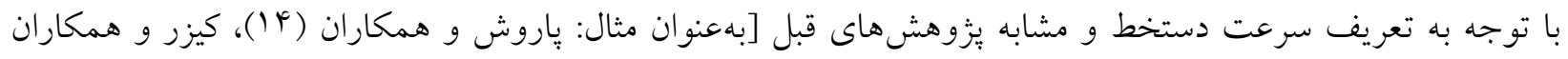
(9 (19)، كلاين و همكاران (VIV)، جوانتاش، ميرزاخانى و يُشازاده (Y9)] سرعت نوشتن به اين صورت ارزيابى شد. هنخامى كه دانش آموز شروع به نوشتن متن انتخابشده مى كرد، از او درخواست مى شد با دستخط معمولى و با سرعتى كه تكاليف خود را مى نويسد، متن را رونويسى كند. يس از ينج دقيقه از دانشآموز خواسته مى شد كه نوشتن را متوقف كند.

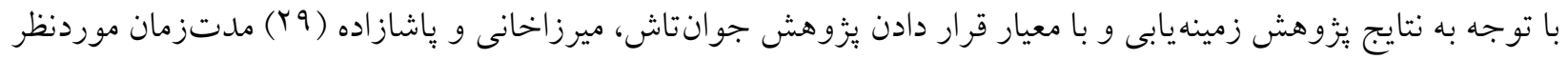
ينج دقيقه انتخاب شد تا شركت كنند گان بهاندازه كافى با شر ايط آزمون آشنا شده و از طرف ديخر از خستكى شركت كنند كان جلو گيرى شود. براى تعيين سرعت نوشتن تعداد حرفهايى كه صحيح نوشتهشده بود شمارش و برحسب حرف در دقيقه محاسبه و ثبت شد. بهمنظور ارزيابى مهارتهاى ادراكى-حركتى شركت كنند كان از شكل بلند آزمون تبحر حركتى برونينكس - أزرتسكى (BOT) الدتفاده شد. اين آزمون براى ارزيابى مهارتهاى حركتى كودكان /2/0 ساله تا ع/2ع ساله طراحى شده و شامل هشت زيرمقياس و آح آيتم است. جهار زيرمقياس مهارتهاى درشت حركتى، سه زيرمقياس

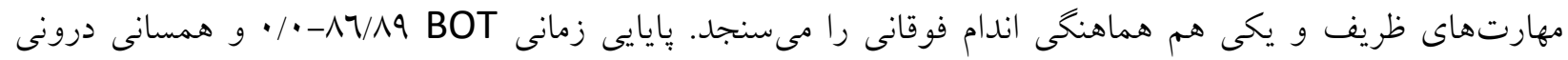

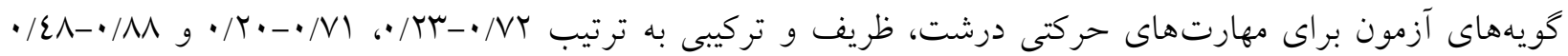
كزارش شده است (•r). در يزوهش هاى داخلى نيز از اين ابزار استفادهشده است ( الr). با توجه به اهداف و منطق تحقيق،

1 Intra-class correlation coefficient (ICC) 0

Buininks-Oseretsky Test of Motor Proficiency (B๑T)

https://jrsm.khu.ac.ir/ 


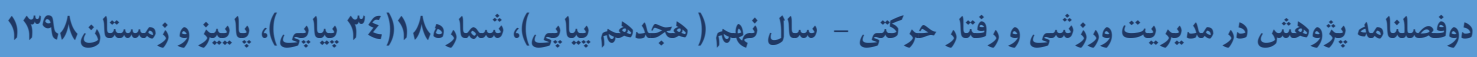

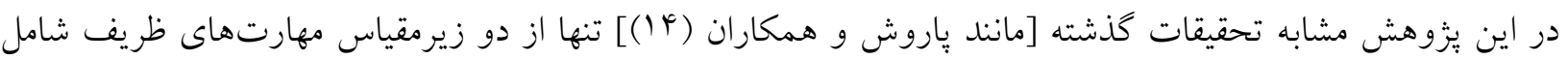

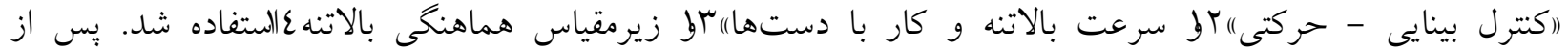
انجام هماهنكى هاى لازم دانش آموزان انتخابشده در دو جلسه يكساعته آزمونهاى مربوط را اجرا كردند. نمونه دستخط هر دانشآموز در اولين جلسه جمع آورى شد. به اين صورت كه متن تهيهشده، يك بركه بدون خط، مداد مشكى و يّاك ركن

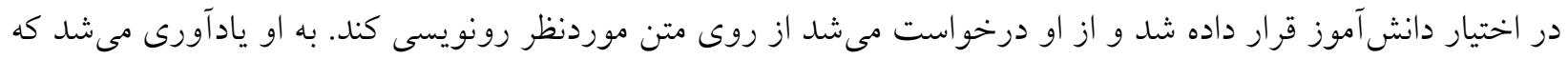
عجله نكند و با دستخط معمولى خود بنويسد. يُس از ينج دقيقه رونويسى متوقف و كد دانش آموز بالاى بركه ثبت مى شد. همه اين آزمونها در سهماهه سوم سال تحصيلى، در فضاى مدرسه و توسط يك آزمونخر انجام شد.

\section{روشهاى آمارى}

براى بررسى ارتباط بين متغيرهاى اندازهگيرى شده در تحقيق از ضريب همبستخى گشتاورى ييرسون استفاده شد. براى مقايسه شاخصهاى كيفيت نوشتن و مهارتهاى ادراكى -حركتى دو كروه دانشآموزان خوش خط و بدخط به ترتيب از

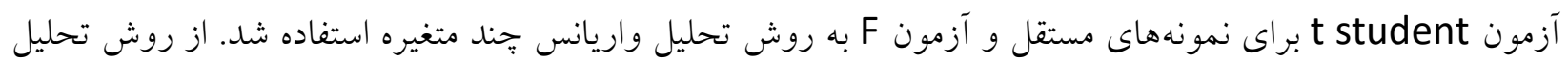
ركرسيون لجستيك به روش كامبه كام استفاده شد تا مشخص شود آيا شاخص هاى كيفيت نوشتن مى تو انند يِيشكويى كننده خوشخطى دانشآموزان هستند يا نه. براى تعيين ييشبينى كنندهاى دو شاخص كيفيت نوشتن از تحليل ركرسيون

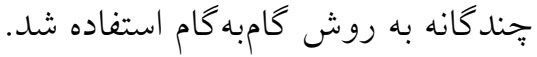

\section{نتـايج}

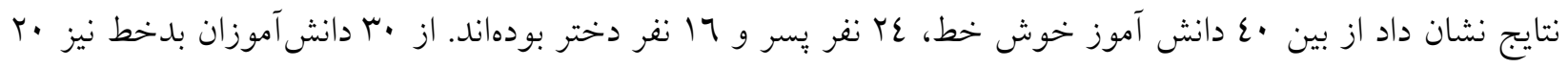
نفر يسر و • انفر دختر بودند. در جدول ا ماتريس همبستكى بين شاخصهاى اندازهيرى شده در تحقيق خلاصه شده است. مطابق نتايج، در هر دو كروه خوشطط و بدخط ضريب همبستحى بين دو شاخص كيفيت نوشتن يعنى خوانايى و سرعت معنادار نيست (0.05 > p). بنابر اين هر يك از اين دو شاخص يكى سازه مستقل را ارزيابى مى كند. نتايج منتخب جدول ا نشان مىدهد در خوشخطها، ضريب همبستكى بين خوانايى نوشتهاى اين دانشآموزان با هيجيك از مهارتهاى اداركى -حركتى معنادار نيست (0.05 > p)؛ اما در بدخطها، ضريب همبستكى بين خوانايى دستخط با

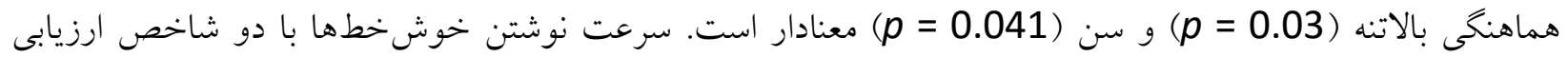
مهارتهاى ادر اكى -حر كتى شامل هماهنكى بالاتنه ( 0.013 =

\footnotetext{
1 Visual-Motor Control (VMC)

1 Upper-Limb Speed and Dexterity (ULSD) 3

1 Upper-Limb Coordination (ULC)
}

https://jrsm.khu.ac.ir/ 


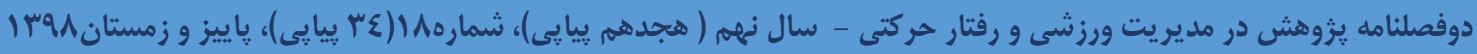

مثت و معنادارى داشت. در بدخطها نيز ضريب همبستكى بين سرعت نوشتن با هماهنكى بالاتنه ( 0.028 = p) و سرعت بالاتنه و كار با دستها (p=0.017) معنادار بود.

طبق نتايج جدول 1، در هر دو گروه خوشخط و بدخط، بين سن با خوانايى دستخط همبستخى معنادار منفى به دست آمد. بنابراين با افزايش سن از خوانايى نوشتهاى كل دانشآموزان كاسته شده است. هم:جنين طبق نتايج حاصل در

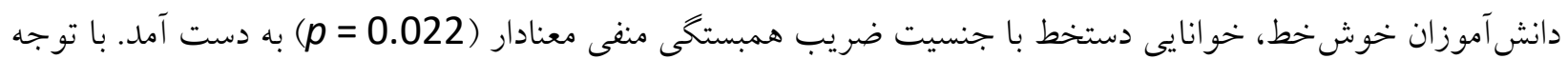
به روش كد كذارى دادها، نتايج نشانگر اين است كه دستخط دخترها خواناتر از يسرها بوده است. طبق نتايج جدول $1 ،$ در هر دو گروه دانش آموزان خوش خط و بدخط، بين سن و سرعت نوشتن همبستخى مثبت معنادار به دست آمد ( > 0.01) كه نشان مىدهد با افزايش سن سرعت نوشتن همه دانشآموزان افزايش يافته است. همجنين مشخص شد در دانش آموزان خوشخط، همبستكى بين جنسيت با سرعت نوشتن مثبت و از نظر آمارى معنادار است (0.018 = p). با توجه به كدگذارى دادهها، نتايج نشانخر آن است كه سرعت نوشتن بسرها بيشتر از دخترها بوده است.

جدول ا. همبستكى بين متغيرهاى اندازهيرى شده در دو گروه خوش خط و بدخط

\begin{tabular}{|c|c|c|c|c|c|c|c|c|}
\hline V & 9 & $\Delta$ & $\varphi$ & $r$ & $r$ & 1 & \multirow[b]{3}{*}{ خوانايى دستخط } & \multirow[b]{3}{*}{1} \\
\hline \multicolumn{7}{|c|}{ كروه بدخط (•r=r) } & & \\
\hline 0.21 & 0.19 & $0.40 *$ & 0.22 & $-0.32 *$ & -0.06 & & & \\
\hline $0.39 *$ & 0.22 & $0.35^{*}$ & 0.26 & $0.35^{*}$ & & -0.03 & سرعت نوشتن & $Y$ \\
\hline 0.26 & $0.34 *$ & 0.24 & $0.31 *$ & & $0.45 * *$ & $-0.54 * *$ & 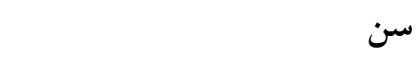 & $r$ \\
\hline $0.41 *$ & $0.31 *$ & -0.20 & & $0.30 *$ & $0.33 *$ & $-0.32 *$ & جنسيت & 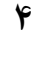 \\
\hline 0.28 & $0.31 *$ & & $-0.53 * *$ & 0.09 & $0.32 *$ & -0.01 & هماهنكى بالاتنه & 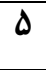 \\
\hline 0.27 & & $0.36^{*}$ & -0.10 & $0.27 *$ & 0.17 & -0.15 & كنترل بينايى -حر كتى & 9 \\
\hline & $0.42 * *$ & $0.42 * *$ & 0.90 & 0.20 & $0.35^{*}$ & -0.11 & سرعت بالاتنه و كار با دستها & V \\
\hline \multicolumn{7}{|c|}{ گروه خوش خط (•ع= } & & \\
\hline
\end{tabular}

تحليل ركرسيون لجستيك به روش كامبه گام انجام شد تا مشخص شود آيا دو متغير بيشخوى خوانايى دستخط و سرعت نوشتن مىتوانند بيشكويى كنند كه آيا يك دانشآموزان خوشخط هست يا نه. طبق نتايج جدول r ، وقتى هر دو متغير باهم در نظر كرفته شوند مىتوانند بهطور معنادارى ييشبينى كنند كه يك دانشآموز خوشخط هست يا خير 41.67, df = 2, N=70, p < 0.001 دانشآموز خوش خط تلقى شود يا نه را مىتوان از روى اين دو متغير وابسته بيشبينى نمود. 


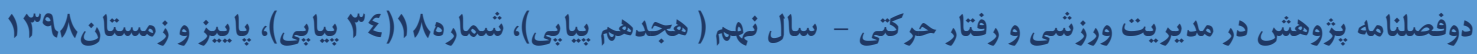

جدول Y. نتايج تحليل ركرسيون لجستيك براى ييشبينى وضعيت خط از روى خوانيى و سرعت نوشتن

\begin{tabular}{|c|c|c|c|c|}
\hline \multicolumn{3}{|c|}{ 95\% C.I. for Odds ratio } & \multirow{2}{*}{ B (SE) } & \\
\hline Upper & Odds ratio & Lower & & \\
\hline .402 & .158 & .062 & $-1.846^{*} .(477)$ & خوانايى دستخط \\
\hline .994 & .982 & .969 & $-.019 * .(007)$ & سرعت نوشتن \\
\hline & 117285.744 & & $11.672 *(2.872)$ & مقدار ثابت \\
\hline
\end{tabular}

تحليل رگرسيون جند گانه به روش كامبه كام براى دو شاخص خوانايى دستخط و سرعت نوشتن روى متغيرهاى اندازه كيرى شده در تحقيق (شامل: سن، جنسيت، كتترل بينايى -حركتى، سرعت بالاتنه و كار با دستها، هماهنكى بالاتنه) انجام شد.

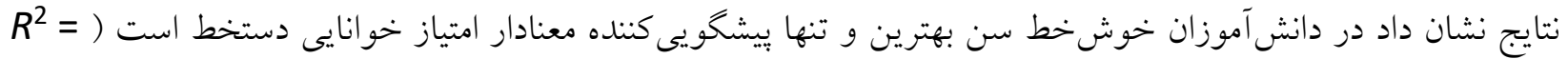
$R^{2}=0.21$; beta = -0.43; $t$ (0.29; beta = -0.54; $t=-3.91, p<0.001$

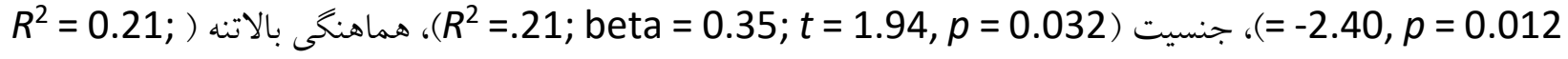
$R^{2}=0.21 ;$ beta = -0.40; $t=2.31, p=$ و كنترل بينايى -حركتى (beta = -0.56; $t=-3.19, p=0.04$ 0.029) بهترين بيشبينى كنندهاى معنادار امتياز خوانايى دستخط هستند. نتايج نشان داد در خوش خططها سه متغير سن

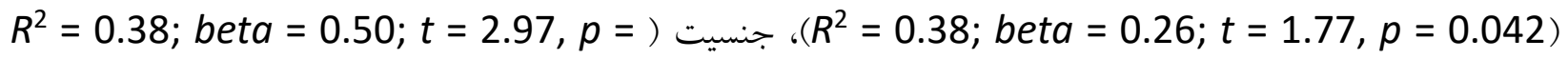

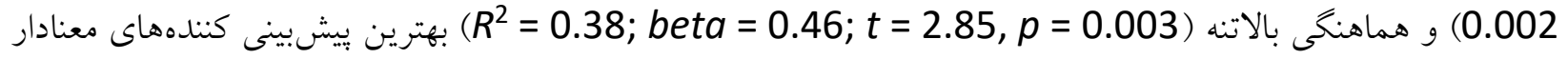
سرعت نوشتن هستند. طبق نتايج، در بدخطها جنسيت (U) هماهنكى بالاتنه

در جدول مل ميانخين و انحراف استاندارد امتياز آزمونهاى كرفته شده از شركت كنند كان خلاصه شده است. نتايج تحليل واريانس جند متغيره (MANOVA) نشان داد بين ميانخين نمرات مهارتهاى ادراكى -حركتى ارزيابىشده تفاوت بين كروهى معنادار وجود نداشت (Wilks' Lambda (0.93), F (3,66) = 1.76, p=0.16) نتايج آزمون تى نشان داد

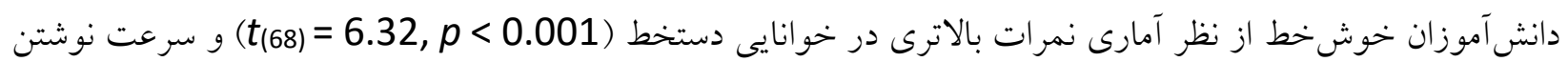
كسب كردماند. 


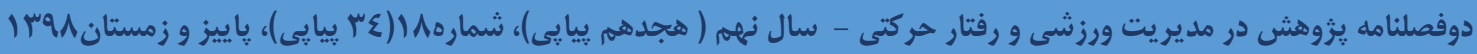

جدول س. ميانخين و انحراف استاندارد امتيازهاى گروههاى خوش خط و بدخط

\begin{tabular}{|c|c|c|c|c|}
\hline \multicolumn{2}{|c|}{ كروه بد خط ( •r)=r } & \multicolumn{2}{|c|}{ كروه خوشخط ( •ع = } & \\
\hline $\mathrm{SD}$ & $M$ & SD & $M$ & \\
\hline 2.28 & 16.73 & 2.28 & 16.73 & مماهنكى بالاتنه \\
\hline 3.08 & 21.56 & 1.93 & 22.60 & كنترل بينايى -حركتى \\
\hline 5.46 & 30.40 & 5.43 & 33.00 & سرعت بالاتنه و كار با دستها \\
\hline 0.94 & 4.04 & 1.02 & 5.55 & خوانايى دستخط*** \\
\hline 11.3 & 29.65 & 9.11 & 36.75 & سرعت نوشتن (حرف در دقيقه)** \\
\hline & & & & 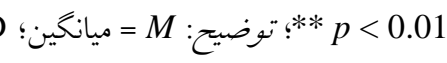 \\
\hline
\end{tabular}

\section{بحث و نتيـجه كيرى}

در يزوهش حاضر ارتباط بين خوانايى و سرعت نوشتن با مهارتهاى ادراكى -حركتى در دانشآموزان فارسىزبان بررسى شد. به اين منظور هماهنكى بالاتنه، كنترل بينايى - حركتى و سرعت بالاتنه و خوانايى دستخط و سرعت نوشتى

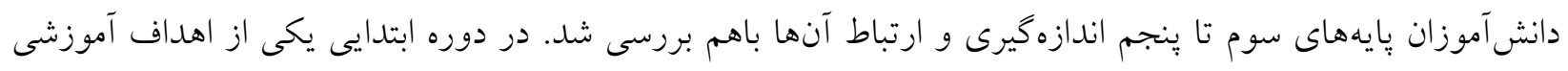

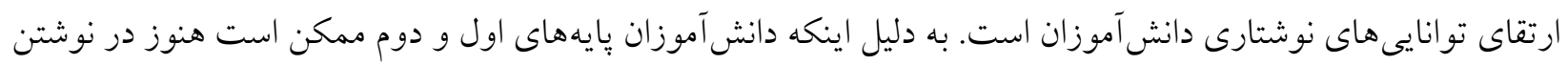
صحيح (املا) برخى از كلمات مشكل داشته باشند، نمونه تنها از يايههاى سوم تا ينجم انتخاب شد.

يكى از اهداف تحقيق بررسى رابطه بين اجزاى نوشتن با مهارتهاى اداركى -حركتى بود. همانطور كه در مقدمه نيز تأكيد شد اعتقاد بر اين است كه با مطالعه و شناسايى آن دسته از مهارتهاى اداركى -حركتى كه زيربناى توانايىهاى نوشتن است مىتوان در ساخت و توسعه برنامهاى رشدى ويزه كه براى برطرف كردن مشكلات دانشآموزان بدخط و داراى

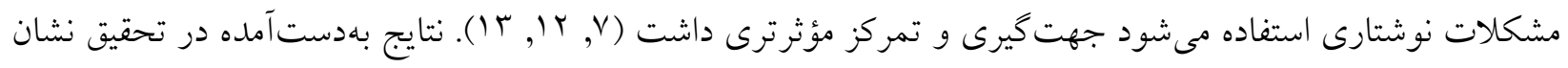
داد در دانشآموزان بدخط بين دو متغير خوانايى دستخط و سرعت نوشتن با هماهنخى بالاتنه ضريب همبستخى مثبت معنادار وجود دارد. بهعبارتديخر ضعف در هماهنكى بالاتنه مىتواند مسبب بدخطى دستخط و كُندنويسى باشد. در

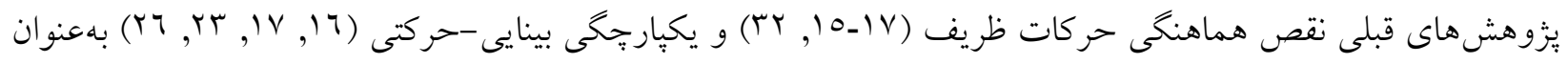
مواردى مرتبط با ضعف نوشتن معرفىشده است. در نگاه اول يافتهاى تحقيق ما نيز اين يافتهها را تأييد مىكند، زيرا

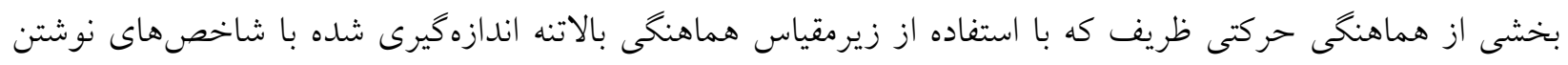
دانش آموزانى كه مشكل دست خط داشتند ارتباط معنادار داشت. ويزّى تحقيق حاضر نسبت به يزوهش هاى مشابه اين است كه اغلب تحقيقاتى كه در مقدمه به آنها اشاره شد روى كودكانى انجامشده كه توأم با مشكلات نوشتارى، مشكلات 


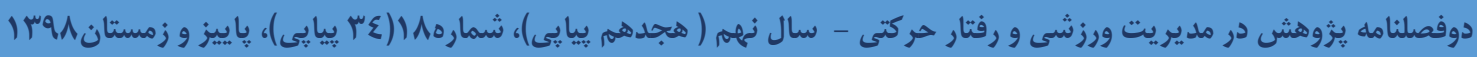

ديكرى مانند اختلال هماهنكى رشدى

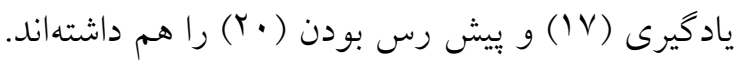

يكى ديكر از اهداف تحقيق يافتن عوامل زيربنايى بيشبينى كننده زير مقياسهاى نوشتن دانش آموزان بود. يافتهاى تحقيق ما نشان داد يِشبينى كنندهاى معنى دار خوانايى دستخط دانشآموزان بدخط به ترتيب سن، جنسيت، هماهنخى بالاتنه و كنترل بينايى -حركتى است. در مورد سرعت نوشتن نيز جنسيت و هماهنكى بالاتنه بهترين بيشبينى كنندهاى معنادار

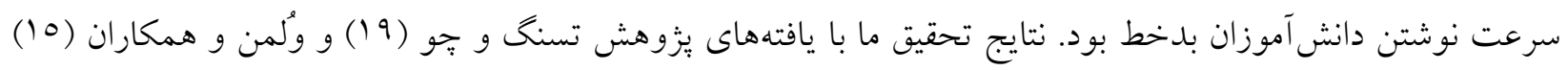
همسو است؛ اما در اين تحقيقات اطلاعاتى در خصوص سرعت و خوانايى نوشتن نمونهاى تحت بررسى كزارش نشده

نتايج تحقيق حاضر نشان داد با استفاده از دو متغير خوانايى دستخط و سرعت نوشتن مىتوان با اطمينان نسبتاً بالايى (بين

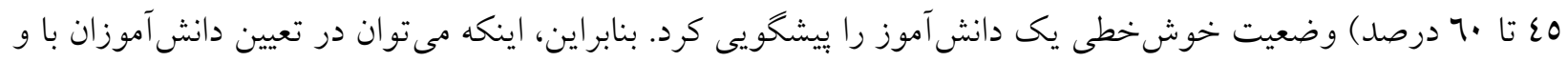

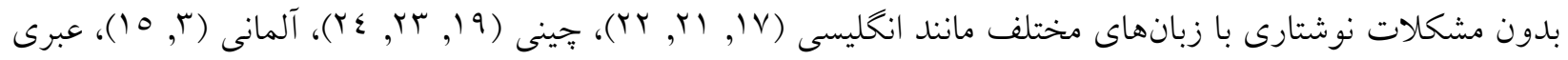
(ع () و فارسى (يزوهش حاضر) از دو شاخص كيفيت نوشتن (سرعت و خوانايى) كمك كرفت مؤيد اعتبار اين دو شاخص است. اين يافته يزوهش حاضر نشان مىدهد عليرغم تفاوت ويزگى هاى فضايى -زمانى و هندسى برخى از زبانهاى بينالمللى، احتمالاً عاملهايى كه مىتوان از آنها براى تمايز اين دانشآموزان استفاده كرد مستقل از زبانهاى نوشتارى دانش آموزان است.

در ادامه شاخصهاى نوشتن (خوانايى دستخط و سرعت نوشتن) و مهارتهاى ادراكى -حركتى دانش آموزان با و بدون مشكلات نوشتن مقايسه شد. يِيش از مقايسه شاخص هاى نوشتن، بايد اين موضوع مهم بررسى مى شد كه آيا اين دو متغير

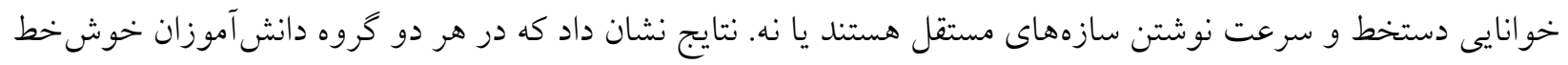
و بد خط همبستكى يايينى بين دو شاخص موردنظر وجود دارد. اين همبستكى يايين كه از نظر آمارى نيز معنادار نبود،

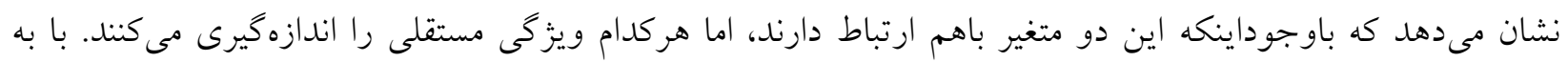
دست آمدن اين نتيجه امكان بررسى فرضيه يُزوهش ميسر شد. نتايج نشان داد دانشآموزان بد خط هم در خوانايى و هم در سرعت از همتايان خوش خط خود ضعيفترند. اين يافتها را مىتوان در راستاى نتايج يزوهشهاى قبلى دانست كه روى دانشآموزان غيرفارسىزبان انجامشده و در آنها شكل حروف، سازماندهى فضايى و خوانايى كلى بررسى شده

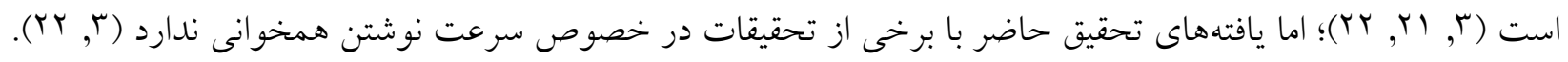
اين عدم همخوانى نتايج مىتواند به ويز گیهاى تكليفهاى خاصى كه در تحقيقات موردنظر استفادهده مرتبط باشد. بهعنوانمثال در يزوهش هامستر -بلز و بولته (r) محدوديت زمانى براى شركت كنند گان اعمال نشده است. در يزوهش

1 Developmental Coordination Disórder (DCD)

https://jrsm.khu.ac.ir/ 


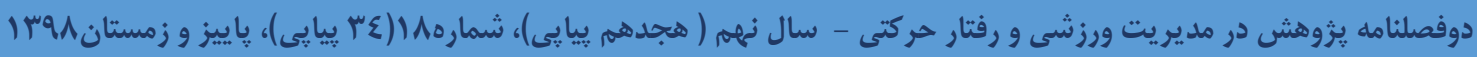

روبين و هندرسون (rT) نيز هر محدوديتى كه باعث سنخين شدن تكليف يا خسته شدن شركت كنند كان شده از بين رفته است. يافتهاى تحقيق ما نشان داد دانشآموزان بد خط مشكلاتى در سرعت نوشتن دارند و تعداد حروفى كه مىتوانند در مدتى مشخص بهدرستى بنويسند كمتر از همتايان خوشط است. بنابراين مىتوان انتظار داشت كه اين دسته از

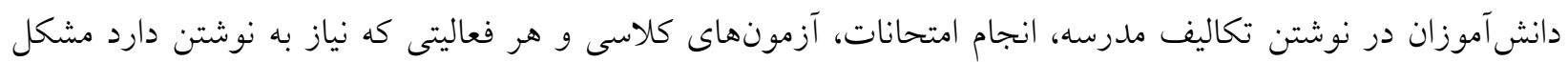
داشته باشند. اين نتيجه گيرى تأييد ديخرى است بر اين يافته يزوهش هاى قبلى كه مشكلات نوشتارى دانشآموزان مىتواند

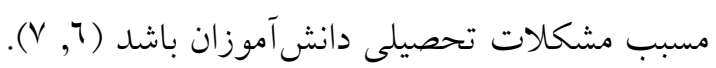

نتايج تحقيق حاضر نشان داد با افزايش سن سرعت نوشتن افزايش يافته است كه البته اين ويزگكى قابل بيشبينى نيز بود. همجنين همبستكى معنادار بين جنسيت با سرعت نوشتن نيز مؤيد اين است كه سرعت نوشتن پِران دانش آموز بالاتر از دخترها بوده است. يافته جالبتوجه و كاربردى اين بود كه با افزايش سن، از خوانايى دستخط دانش آموزانى كه از نظر معلمشان مشكلى در نوشتن نداشتند و خوشطط محسوب مىشدند كاسته شده است. بنابراين مىتوان نتيجه كرفت دانش آموزان موردنظر بين سرعت-دقت مبادلهاى انجام دادهاند و با افزايش سن و بهتبع آن يايه تحصيلى، سرعت را فداى دقت (زيبانويسى) در نوشتن كردهاند. طبق قانون مبادله سرعت-دقت يكى از نتايج توجه بهسرعت مىتواند اشتباه نوشتن حروف و توجه كمتر به خط زمينه باشد كه همين موضوع باعث ايجاد متنى مىشود كه از خوانايى مطلوب بى بهره است. به نظر مىرسد اين يافته با رويكرد حاكم در مدارس ابتدايى كشور در ارتباط است. برخى از معلمان و والدين در بايههاى

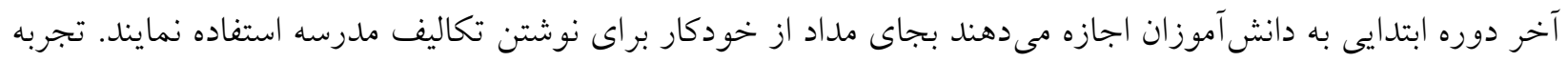
ما نشان مىدهد اغلب نوشتههايى كه بهوسيله مداد نوشته مىشوند خوشخطتر از آنهايى است كه با خودكار نوشته مىشوند. بنابراين باو جوداينكه ما در تحقيق خود بررسى نكرديم كه دانشآموزان تحت بررسى از جهه وسيلهاى براى نوشتن

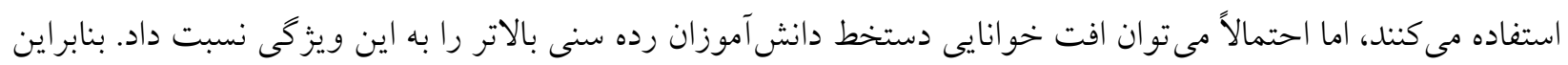

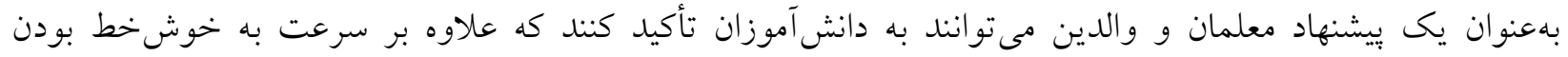
نوشتهاى خود نيز توجه نمايند و نوشتن بهوسيله مداد را توصيه نمايند.

بيش از يرداختن به بيشنهادهاى كاربردى برخاسته از تحقيق بايد به محدوديتهاى طرح تحقيق اشارهكنيم. كم بودن تعداد نمونه در يزوهش هاى همبستكى هميشه مسئله مهمى است كه در تعميم نتايج بايد به آن توجه ويزه شود و يزوهش حاضر نيز از آن مستثنا نيست. علاوه بر اين بايد به اين نكته نيز اشاره نمود كه نمونه تحقيق حاضر تنها از يكى منطقه جغر افيايى با ويزگكىهاى فرهنكى مشترى انتخاب شد. استفاده از آزمونهاى منتخب طرح تحقيق نيز محدوديت ديخرى است كه

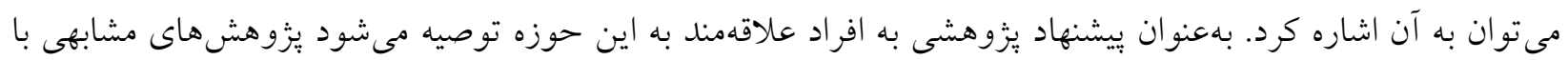
حجم نمونه بالا، انتخاب نمونه با ويزگى هاى جغر افيايى -فرهنكى متفاوت و ديخر ابزارها، بهجز آنجه در اين تحقيق استفاده 


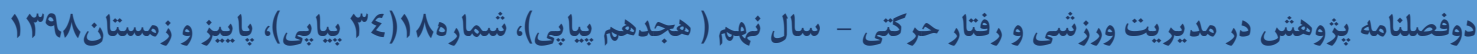

شد، انجام دهند. با توجه به نتايج در تحقيقات بعدى مى توان مزيتهاى استفاده از برنامهاى مداخلهاى براى تشويق به انجام مهارتهاى ادراكى -حركتى و نوشتن، به منظور ارتقاى عملكرد در اين دو حيطه را بررسى نمود.

تحقيق حاضر شو اهدى مبنى بر ارتباط بين مهارتهاى اداركى -حركتى و خوانايى / سرعت نوشتن فراهم نمود. نتايج تحقيق حاضر از يك طرف تأييد كرد كه نوشتن مهارتى بييجيده است و از طرف ديخر مهر تأييدى است بر اين ديدكاه كه بهر

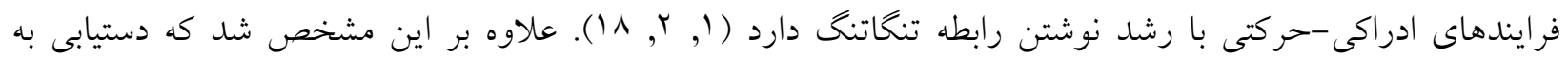
دستخطى در سطح مطلوب نهتنها با بلوغ و اجزاى ادراكى مرتبط است، بلكه به مهارتهاى حركتى نيز وابسته است. نتايج يُزوهش حاضر مىتواند به معلمان، فيزيوترابٍ ها، كار درمانها و يزشكان كمك كند تا جنبههاى خاصى از مشكلات نوشتارى را بهتر توصيف و مشخص نمايند و برنامههاى مداخلهاى مؤثرترى كه بهويزه فرايندهاى زيربنايى رشد هماهنخى بالاتنه، سرعت بالاتنه و كار با دستها و كتترل بينايى-حركتى را دركير نمايد براى برطرف كردن مشكلات نوشتارى دانشآموزان ارائه دهند. در تحقيقات بعلى مىتوان مزيتهاى استفاده از برنامههاى مداخلهاى شامل تشويق به انجام مهارتهاى ادراكى -حركتى و نوشتن، بهمنظور ارتقاى عملكرد در اين دو حيطه را بررسى نمود. به اين اميد كه با بهبود

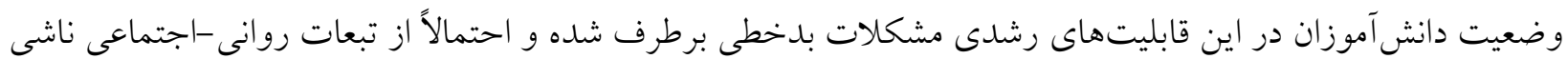
از مشكلات نوشتارى كاسته شده، موجبات فعاليت ثمربخشتر آنان در فعاليتهاى متنوع مدرسه فراهم گردد.

\section{تشكر و قدردانى}

اين بزّوهش با حمايت مالى معاونت يزوهشى دانشگاه اصفهان انجام شده است. نويسند كان وظيفه خود مى دانند از تمامى دانش آموزان، والدين و معلمانى كه با ما در انجام اين يزووهش همكارى نمودند صميمانه تشكّر و قدردانى نمايند. 
1. Graham S, Weintraub N. A review of handwriting research: Progress and prospects from 1980 to 1994. Educational Psychology Review. 1996;8(1):7-87.

2. Laszlo JI, Bairstow PJ. Handwriting: Difficulties and possible solutions. School Psychology International. 1984;5(4):207-13.

3. Hamstra-Bletz L, Blote AW. A longitudinal study on dysgraphic handwriting in primary school. Journal of Educational Psychology. 1993;26:689-99.

4. Karlsdottir R, Stefansson T. Problems in developing functional handwriting. Perceptual \& Motor Skills. 2002;94:623-62.

5. Hosseinaee A, Ahmad A, Azam N. Prevalence of reading and writing disabilities among primary school students. Developmental Psychology: Iranian Psychologists. 1390/2011;7(28):353-63 (In Persian).

6. Gregg N, Mather N. School is fun at recess: Informal analysis of written language for students with learning disabilities. Journal of Learning Disabilities. 2002;35:7-22.

7. Feder KP, Majnemer A. Handwriting development, competency, and intervention. Developmental Medicine \& Child Neurology. 2007;49(4):312-7.

8. World Health Organization. International checklist of functioning, disability and health: ICF (Version 2.1a). 2002. Geneva, Switzerland: Author.

9. Sovik N, Arntzen O, Karlsdottir R. Relations between writing speed and some other parameters in handwriting. Journal of Human Movement Studies. 1993;25(3):133-50.

10. Graham S. The relationship between handwriting style and speed and legibility. The Journal of Educational Research. 1998;91:290-7.

11. Graham S, Weintraub N, Berninger V, Schafer W. Development of handwriting speed and legibility in Grades 1-9. The Journal of Educational Research. 1998;92(1):42-52.

12. Howe TH, Roston KL, Sheu CF, Hinojosa J. Assessing handwriting intervention effectiveness in elementary school students: a two-group controlled study. The American Journal of Occupational Therapy. 2013 Jan;67(1):19-26.

13. Taras H, Brennan J, Gilbert A, Eck Reed H. Effectiveness of Occupational Therapy Strategies for Teaching Handwriting Skills to Kindergarten Children. Journal of Occupational Therapy, Schools, \& Early Intervention. 2011;4(3-4):236-46.

14. Parush S, Lifshitz N, Yochman A, Weintraub N. Relationships between handwriting components and underlying perceptual-motor functions among students during copying and dictation tasks.. OTJR: Occupation, Participation and Health. 2010;30(1):39-48.

15. Volman MJM, van Schendel BM, Jongmans MJ. Handwriting difficulties in primary school children: A search for underlying mechanisms. The American Journal of Occupational Therapy. 2006;60(4):451-60.

16. Kaiser M-L, Albaret J-M, Doudin P-A. Relationship between visual-motor integration, eyehand coordination, and quality of handwriting. Journal of Occupational Therapy, Schools, \& Early Intervention. 2009;2(2):87-95.

17. Klein S, Guiltner V, Sollereder P, Cui Y. Relationships between fine-motor, visual-motor, and visual perception scores and handwriting legibility and speed. Physical \& Occupational Therapy in Pediatrics. 2011;31(1):103-14. 
18. Berninger VW, Swanson HL. Modifying Hayes and Flower's model of skilled writing to explain beginning and developing writing. Advances in Cognition and Educational Practice. 1994;2:5781.

19. Tseng MH, Chow SM. Perceptual-motor function of school-age children with slow handwriting speed. The American Journal of Occupational Therapy. 2000;54(1):83-8.

20. Feder KP, Majnemer A, Bourbonnais D, Platt R, Blayney M, Synnes A. Handwriting performance in preterm children compared with term peers at age 6 to 7 years. Developmental Medicine and Child Neurology. 2005;47(3):163-70.

21. Graham S, Boyer-Shick K, Tippets E. The validity of the handwriting scale from the test of written language. Journal of Educational Research. 1989;82:166-71.

22. Rubin N, Henderson SE. Two sides of the same coin: Variations in teaching methods and failure to learn to write. British Journal of Special Education. 1982;9:17-24.

23. Tseng $\mathrm{MH}$, Murray EA. Differences in perceptual-motor measures in children with good and poor handwriting. Occupational Therapy Journal of Research. 1994;14(1):19-36.

24. Li-Tsang CW, Au RK, Chan MH, Chan LW, Lau GM, Lo T, et al. Handwriting characteristics among secondary students with and without physical disabilities: A study with a computerized tool. Research in Developmental Disabilities. 2011;32(1):207-16.

25. Alibakhshi SZ, Aghayousefi AR, Zare H, Behzadipour S. Efficacy of self-regulated strategy development on writing performance of students with attention deficit hyperactivity disorder. Journal of Applied Psychology. 2011/1390;5(2):37-47 (In Persian).

26. Hadavandkhani F, Bahmani H, Behnia F, Farahbod M, Salehi M. Relationship between visual-motor integration and handwriting in mentally retarded students. Research on exceptional Children. 1385/2007;7(1):98-112 (In Persian).

27. Hadavandkhani F, Bahmani H, Behnia F, Farahbod M, Salehi M. The association of visualmotor integration with handwriting in mentally retarded students. Research on Exceptional Children. 2007; 1386;23(1):97-112 (In Persian).

28. Dewey D, Tupper DE. Developmental motor disorders: A neuropsychological perspective. Bornstein RA, editor. New York \& London: Guilford Press; 2004.

29. Javantash A, Mirzakhani N, Pashazadeh Z. The quest for exploring the normal speed of handwriting in students of grade 2-5 in Tehran. Quarterly Journal of Medical Rehabilitation. 1391/2012;1(1):81-73.

30. Bruininks $\mathrm{RH}$. Bruininks-Oseretsky test of motor proficiency: Examiner's manual. Circle Pines, MN: American Guidance Service; 1987.

31. Salehi H, Afsordeh Bakhshayesh R, Movahedi A, Ghasemi V. Psychometric properties of a Persian version of the Developmental Coordination Disorder Questionnaire in boys aged 6-11 year-old. Quarterly Psychology of Exceptional Individuals. 1390/2012;1(4):135-61 (In Persian). 32. Smits-Engelsman BC, Niemeijer AS, Van Galen GP. Fine motor deficiencies in children diagnosed as DCD based on poor grapho-motor ability. Human Movement Science. 2001;20(12):161-82 